\title{
Diglossic communities in transition: the cases of the Limburgs and Swabian speech communities in Australia ${ }^{1}$
}

\author{
ANNE PAUWELS
}

The study of multilingualism in Australia has always placed great emphasis on the investigation of the language-maintenance (henceforth LM) and languageshift (henceforth LS) patterns of immigrant communities. It has been regarded, right from the start, as an important area of research which contains information crucial to related issues such as language policy and bi- and multilingual education.

Traditionally, sociology-of-language research in the Australian immigrant context has tended to assume an isomorphism of nation/state and ethnolinguistic group; for example, the language-use patterns of the Poles, the Dutch, the Italians, the Greeks were examined. Unfortunately, this concentration on the linguistic examination of 'national' groups has led to the ignoring of the fact that many nations/states encompass a diversity of ethnolinguistically distinct subgroups who may very well hold different attitudes toward LM and LS (for other evidence, see also papers by Kouzmin and Clyne in this issue).

It is my intention in this paper to investigate the language-use patterns of two ethnolinguistic subgroups, the Limburgers (ethnic group: Dutch, state: The Netherlands) and the Swabians (ethnic group: German, state: West Germany), who as groups represent speech communities which are characterized by diglossia and are embedded in larger ethnic and speech communities (Dutch or German). I shall argue that the analysis of the language-use patterns of such groups may shed further light on the processes of LM and/or LS which may in turn affect practical language-policy matters as well as theoretical insights into the dynamics of language contact and change.

\section{Diglossia}

It is beyond the scope of this article to include a lengthy critique of diglossia as it has developed over the last three decades. It seems to have become a common practice for anyone describing a diglossic language situation to 
include an in-depth analysis of the concept and consequently to justify the use of the term 'diglossia' in the description of that specific language situation (for more information, see Pauwels 1984, 1986a, 1986b).

Ever since Ferguson (1959) first introduced 'diglossia' to the AngloAmerican and Germanic (socio)linguistic spheres, the concept has been surrounded by controversy. By the mid-1960s the main point of confrontation had become the question of which criteria and how many features as described by Ferguson (1959) were necessary to label a language situation as diglossic. Two viewpoints came to dominate. The first was associated with Ferguson's description of diglossia and proclaimed that any language situation which did not display all nine features described by Ferguson (1959) should not be called diglossia. Later 'full diglossia' (Timm 1981) or 'diglossia à la Ferguson' were used to describe this type of diglossia. The second point of view had developed from the writings of Gumperz (1962, 1964) and Fishman (1967), who placed great emphasis on the importance of the feature of 'functional differentiation between the language varieties' in considering a language situation diglossic. It is this stress on the feature of 'function' (sometimes resulting in the neglect of the other features) which led to such labels as 'domain-complementarity diglossia' (Timm 1981) or 'diglossia à la Fishman'. The pros and cons of the maximalist and minimalist definitions of diglossia have been the subject of many articles on diglossia in recent years. Those adhering to a maximalist Fergusonian definition have generally suggested that the solution to the controversy lies in more or less depriving those language situations not in line with full diglossia of their diglossia epithet. Others, including those supporting the minimalist definition have argued that in realistic terms, it is impossible to return to the original 'nine features' type of diglossia, because of the widespread use of the term diglossia to describe a great variety of very different language situations and linguistic communities. Their suggestions for a resolution of the diglossia controversy mainly run along the lines of setting up a typology of diglossic relations and situations, and thus giving the term diglossia supernymic status (see Haarmann 1983; Pauwels 1986a). In such typologies full diglossia and domain-complementarity diglossia would be seen as two of the many different types of diglossia found among the linguistic communities of the world.

I would like to align myself with the minimalist approach to diglossia and would like the reader to understand my use of the term diglossia in reference to the minimalist definition. 
The investigation: Limburgs and Swabian diglossia in transition

\section{Aim of the investigation}

The purpose of the investigation is to establish to what extent the diglossic nature of two speech communities has been affected by the process of migration and whether possible changes in the diglossic constellation have a bearing on the future of these speech communities in Australia.

\section{Method: sampling of data}

Assessing the effect of migration on the language behavior of the Limburgers and Swabians implies the sampling of data illuminating their pre- and postmigration language behavior. Rather than relying on existing sociolinguistic descriptions of the language situation prevalent in Limburg and Swabia (Württemberg), it was decided to ask the selected informants to describe their language use in a number of domains prior to and after migrating to Australia. $^{2}$

The informants' language-use patterns were established by means of an interviewer-administered questionnaire. The questions were oriented toward examining language-use patterns in the domains of family, (ethnic) friendship, ethnic clubs and societies, ethnic church, and employment, with specification of interlocutors, locales, and topic for each domain. To obtain a more accurate insight into language use associated with ethnic clubs and organizations, a societies questionnaires was added (see Pauwels 1986b).

\section{The informants}

Fifty Limburgers and 50 Swabians made up the sample of informants for this study. ${ }^{3}$ Because of the relatively small size of the sample, care was taken to select informants who were not related to or acquainted too closely with other members of the sample. The Limburgs sample consisted of 25 men and 25 women; the age range was 26 to 72 years, with 51 years being the average. Eighty percent of the Limburgers had arrived in Australia during the 1950s; the rest had arrived between 1960 and 1966. Most had come to Australia as adults (only four had come in their mid-teens). A wide range of occupations was represented in the sample but the trend was toward skilled workers and tradespeople. Most informants had received some form of secondary education as well as some vocational training. The Swabian group was very similar to the Limburgs group: 25 women and 25 men whose 
ages ranged from 35 to 75 years, the average being 52 years. Sixty percent of the Swabian informants had arrived in the 1950s and the rest in the early or mid-1960s. All except two informants had come to Australia as adults. With regard to education and professional training as well as occupation, the Swabians were very similar to the Limburgers.

\section{Language use patterns in the home country}

The Limburgers. Two language varieties, Standard Dutch and a Limburgs dialect, ${ }^{4}$ seemed to constitute the language repertoire of all the Limburgs informants. In the informants' opinions there was a clear-cut distinction between Standard Dutch and the Limburgs dialect at both the linguistic and the functional levels: the two varieties were seen as separate language systems, each with its own phonology and lexicon, which did not greatly overlap. This lay view of the linguistic distinctiveness of the two varieties is in line with sociolinguistic descriptions (see for example Hagen 1975, 1980, 1981) which have pointed out the massive language difficulties some young dialect speakers (in Kerkrade) face at school, where Standard Dutch is considered the main and appropriate language code. There was also a general consensus about the functional differentiation between the two varieties. The standard language (Standard Dutch) was seen to be the appropriate variety to use in almost all forms of written communication (except dialect poetry and literature) and for formal speech/speech functions in the domains of the church, ${ }^{5}$ the school, employment, and local government. The standard language in its spoken form also functioned as 'lingua franca' in (formal and informal) communication with non-Limburgs-speaking Dutch. The Limburgs dialect dominated in all other language situations. Furthermore there was also a special link between Limburgs and the festival of Karneval/Carnaval which is the pre-Lent festival celebrated by many Catholics around the world (the most famous one being the Carnival of Rio di Janeiro). Karneval activities in Limburg include the election and crowning of a Prince Karneval, the abdication of the previous year's Prince, a Karneval train through the streets of the town/ city, and various activities involving a number of rituals. The rituals and songs linked to Karneval are conducted in the dialect. The image obtained of the language situation in Limburg during the 1950s and early 1960s has many of the features characteristic of a diglossic situation: Standard Dutch fulfilled the role of the High variety, which was usually acquired later in life. The Limburgs dialect functioned as Low variety. Most Limburgers during that period experienced primary socialization in the dialect. Elsewhere (Pauwels 1986a, 1986b) I labeled this situation rigid diglossia with rigid referring to a rigid functional and linguistic differentiation between the two varieties. 
The Swabians. In the case of the Swabian informants, their answers to the questions regarding language use in Swabia (Württemberg) were also very consistent with scholarly reports on the language situation in Württemberg in the 1950s and 1960s (see Engel 1954, 1961, 1962). The situation can be summarized as follows: informants were unanimous about the functional differentiation between Standard German and the Swabian dialect. The more formal speech functions in the domains of the church, the school, and local government were linked to Standard German. Written communication was also linked to the standard language. The Swabian dialect was seen as the appropriate variety for communication of an informal nature in the domains of family, friendship, even work and school. The Swabian situation, however, is different from that of Limburgs with regard to the perception of the linguistic distinctiveness of the varieties: whereas Limburgers appear to assess the relationship between Standard Dutch and the Limburgs dialect as a dichotomous one, Swabians are more likely to present it in terms of a continuum. Depending on the speaker's socioeducational as well as geographical (urban-rural) background, he/she may have been socialized in a dialectal variety which is linguistically more or less distant from Standard German. Informants from rural areas and those belonging to lower socioeconomic strata were found to use a dialect variety more remote from the standard language than informants from urban areas and larger cities (Tübingen, Stuttgart, etc.) or from higher socioeconomic strata, who often acquired as their first language variety a form of dialect that is linguistically closer to Standard German.

Although there may not have been the same degree of consensus in the Swabian community on the precise linguistic boundaries between the High variety and the Low variety as in the Limburg community, there was nevertheless a genuine belief among the informants that a formal situation required the use of the High variety, that is, Standard German or a variety close to Standard German. In Pauwels (1986a, 1986b) I labeled the Swabian language situation fluid diglossia. The situation is diglossic as there is unanimous recognition that separate varieties are used for High and Low language functions. Fluid refers to the fact that the linguistic boundaries between the two varieties are less clear-cut.

\section{Language use patterns in Australia}

Preliminary: Dutch and German in Australia. Although this paper is not concerned with the comparison of the maintenance patterns of Dutch and German speakers or with an analysis of the language behavior of either the Dutch or the German community at large, the following figures regarding 
LM and LS rates pertaining to Dutch and German in Australia may enhance the understanding of the linguistic behavior of the two subgroups examined in this paper.

Figures based on the 1976 census indicate that the Dutch community has experienced a considerable shift to English in the first generation: $43.55 \%$ of first-generation Dutch immigrants no longer (regularly) use Dutch. For the second generation the LS rate amounts to approximately $81 \%$ (Clyne 1982). As a matter of fact the Dutch are the ethnic group which has recorded the highest rate of LS.

Rate of LS among first-generation immigrants from Germany was found to be around $27.79 \%$ and for the second generation around $61.82 \%$. These differences in LM/LS rates between the German and the Dutch group will be reflected in the LM patterns of their respective subgroups.

\section{The Limburgers}

The replies given by the 50 quite 'different' Limburgs informants regarding their (non)use of Standard Dutch were very similar to each other. This may suggest that the Limburgers in Australia still regard themselves very much as a separate group from other Dutch immigrants and as a speech community which does not coincide with the Dutch speech community in Australia. Rather than level out the intraethnic and intralingual differences (that is, between Limburgers and other Dutch speakers) which existed in the home country and which may have arisen from territorial divisions between Limburgers and other Dutch, emigration to Australia and the breaking down of the territorial divisions appear to have exacerbated existing lingual differences. The original stable, intralingual (between Standard Dutch and Limburgs) diglossia of the Limburgs speech community has made way for a new, possibly less stable form of interlingual (between English and Limburgs) diglossia. From data pertaining to the language-use questionnaires it became clear that for the majority of (first-generation) Limburgers, Standard Dutch as the High language had been replaced by English as soon as their proficiency in English became sufficient to warrant its use. There seems to have been almost no resistance, on either a personal or a group level, to the swift replacement of Standard Dutch by English. This swift replacement primarily affected language domains and language functions which were closely associated with the wider (Anglo-)Australian community or with Australian institutions and thus could be expected to undergo a more rapid shift to English: for example, employment, education, contact with the authorities. In addition, Standard Dutch became obsolete as the High language in domains and situations more clearly reflecting the Dutch/Limburg ethnic community in Australia. English 
has also overwhelmingly replaced Standard Dutch as the lingua franca between Limburgers and other Dutch speakers (see also friendship domain). Though English is also increasingly used in Low language domains and situations, formerly the exclusive reserve of Limburgs, the process of language shift in the latter is much slower and some resistance is experienced.

In the following sections I shall describe in detail the language-use patterns of Limburgers in various domains so as to illustrate the differences in the process of language shift from Limburgs to English and from Standard Dutch to English.

Family domain. Limburgers do not behave differently from other Dutch speakers with regard to language use in the family (see also Pauwels 1986b). Communication between spouses is predominantly in the first language (L1), that is, Limburgs $(85.4 \%)$, as is communication between the informants and their parents. Interaction between the informants and their children, however, is dominated by the use of English (English: 60.4\%, Limburgs: 37.5\%). Standard Dutch, in its function as the code for written communication, has been maintained with regard to correspondence between the informants and their overseas relatives. Sometimes informants also use Standard Dutch when writing to older relatives or parents living in Australia. Shopping lists, reminder notes, etc., are usually written in a mixture of English and Standard Dutch. Written communication of whatever kind between the informants and their (Australian-born) children is in English.

Friendship domain. In encounters between Limburgers and their AngloAustralian or non-Dutch friends and acquaintances, the language used is English. After all, English is the only viable code in this context as it is the lingua franca of interethnic communication in Australia. However, English is also predominantly used in encounters between Limburgers and their non-Limburgs-speaking Dutch friends and acquaintances (English: 74\%, Standard Dutch: 9\%, Limburgs: 17\%). As far as the Limburgers were concerned, Standard Dutch appeared to have made way for English as the lingua franca for interaction with non-Limburgers. This observation is quite remarkable considering the reports by their potential interlocutors, non-Limburgsspeaking Dutch, who were less emphatic about using English in interaction with fellow Dutch friends, including Limburgers: use of English: 32\%, Standard Dutch: 68\% (see Pauwels 1986b for more details). On the basis of this type of data (reported language use) one can only speculate about the actual language used in such encounters: either the parties involved employ two languages, that is, the Limburgs party uses English and the Dutch party Dutch, or one of the parties shifts to the language used by the other. It is most likely in the case of Dutch immigrants in Australia that the shift will be 
toward English rather than Dutch. However, only data from interactional studies could confirm or deny these speculations.

With regard to interaction among Limburgers in the friendship domain, Limburgs is still the dominant code used, at least in the first generation. Written language use associated with this domain does not differ from that found in the family domain.

Ethnic-Limburgs clubs and societies. In Melbourne as well as in other major Australian cities Limburgers have set up a number of social clubs usually focusing on the festival of Karneval. In Australia Karneval clubs perform two functions for the Limburgers: besides their role as bearers of Limburgs traditions and culture, the Karneval clubs also act as a meeting place for Limburgers outside the Karneval season. As organizers of the Karneval festivities they also attract a variety of 'outsiders' (other Dutch immigrants, Anglo-Australians, Germans, Italians, etc.) during the festival.

The dominant language of Karneval celebrations is Limburgs. All the ceremonial texts and rituals are in the Limburgs dialect with the commentary/ linking texts in a mixture of English and Limburgs (see Pauwels 1986b for more details). Other social activities (such as snooker, billiards, card games, etc.) are usually in Limburgs if only Limburgers participate and in English if other groups are involved (see friendship domain).

The language of meetings (for example, AGMs, board meetings: Standard Dutch would be considered the appropriate code in the Netherlands) associated with Limburgs societies in Australia is English, despite the fact that the members of the board/the participants in the meeting are almost all first-generation Limburgers with a good command of Standard Dutch, and despite the fact that the meeting procedures do not exactly follow AngloSaxon meeting routines (see Clyne and Manton 1979). The meetings of the Raad van Elf [Council of Eleven] which prepare the Karneval festivities are held in the dialect (Limburgs), but the minutes, like those of non-Karneval meetings, are in English.

English has also become the code for almost all forms of written communication associated with Limburgs societies. In Australia correspondence between Limburgs and non-Limburgs Dutch clubs is almost exclusively in English. Whereas some Dutch clubs still publish their bulletins or newsletters in Standard Dutch or a mixture of Dutch and English, none of the surveyed publications of Limburgs clubs use Dutch. The latter's newsletters are mostly in English, with sections about Karneval events in Limburgs or in a mixture of English and Limburgs.

Work domain. For most Limburgers the domain of employment is an exclusively English-language domain, as they work outside their ethnic and/ 
or regional group. Five Limburgers had established small family businesses which employed mainly Limburgers and other Dutch immigrants. Where the entire staff was Limburgs, a mixture of Limburgs and English was spoken. If the staff included non-Limburgs-speaking Dutch workers, it was common practice to speak English. Two male informants worked for a Dutch employer (family catering business). They spoke English with their employer and the other staff. All written communication associated with this domain was in English.

School domain. Neither the Dutch as a national nor the Limburgers as a regional group have set up ethnic language schools or language courses to teach Dutch to the second and subsequent generations. This domain was one of the first to become completely anglicized.

Church domain. Those Limburgs informants who had a religion were Roman Catholics. In the 1950s and 1960s the Roman Catholic Church in Australia regarded the existence of church services and Mass in LOTEs as a transitional measure to facilitate the assimilation of Catholics of non-Englishspeaking backgrounds into church services conducted in the English language. However, more recently Roman Catholic parishes have come to support a more pluralist model (see Clyne 1982).

Dutch Catholics in Melbourne can attend a Dutch-language Mass once a month. Similar facilities exist in other cities around Australia. For the Limburgers, the ethnic church domain is the only domain in which Standard Dutch is maintained as High language. However, Limburgers like other Dutch immigrants do have a choice of whether to attend Mass in an Australian, English-speaking parish or in the Dutch one. As a matter of fact, very few informants attended the Dutch Mass.

\section{The Swabians ${ }^{6}$}

The data on the language use of the Swabian informants revealed quite different language patterns from those of the Limburgers. They have maintained their original intralingual, fluid diglossia much better, at least with regard to interactions in the ethnic community. Both Standard German and Swabian, though facing increasing competition from English in all domains, are still very much part of a first-generation Swabian's language repertoire. In the Swabian case, it appears likely that the Low language, Swabian, and the original High language, Standard German, will experience a shift to English at the same rate and more or less simultaneously. The language data seem to imply that in the process of migration the Swabian speech community has 
aligned itself with and integrated itself into the 'German' speech community, thus stressing its Germanness rather than its Swabianness, at least in language terms.

Family domain. The language-use patterns found in Swabian families were similar in some respects to those found in Limburgs families. The dialect again was the main variety used between spouses (dialect: $85.4 \%$, Standard German: 8.3\%, and English: 6.3\%). When speaking with their children, informants still made substantial use of the dialect (52.1\%). Some parents used Standard German with their children (20.8\%). Only $27.1 \%$ of informants indicated that they used English with their offspring. The latter is in stark contrast to the Limburgs situation where $60.4 \%$ of the parents used English with their children. The dialect also remained the only language variety in communication with the older generation (parents, grandparents). Standard German remained the written code with regard to correspondence between the informants and their overseas relatives as well as between themselves and their (elderly) relatives or parents in Australia. Personal shopping lists, etc., were usually written in a mixture of Standard German and English. Reminder notes, etc., for the children were also either in English or in a mixture of English and Standard German.

Friendship domain. With regard to ethnic friendship patterns the Swabian informants seemed to have befriended both Swabian and other Germanspeaking immigrants. In their interregional (between Swabians and other Germans) encounters, the Swabian informants indicated that they preferred to use either Standard German or a mixture of Standard German and Swabian rather than English (Standard German: 60\%, mixture: 19\%, English 24\%). In their encounters with other Swabians the dialect did not as yet experience a great deal of competition from English (Swabian: 89\%, English: 11\%). Written communication between friends and/or acquaintances followed the same patterns as among family members.

Ethnic clubs - Swabian societies. At the time when the research for this article was carried out (1980-1983) there were no clubs or societies in Melbourne that catered mainly for Swabians or that had a distinctively Swabian character. In 1983 the first Swabian club, Schwaben Klub, was established in Melbourne. Communication patterns on the interpersonal level did not distinguish themselves from those linked to the domain of friendship. As the club does not hold formal meetings, it is impossible to assess whether Standard German has been maintained in this $\mathrm{H}$ function.

If Swabian informants had joined other clubs, their language behavior during social activities was again similar to that found in the friendship 
domain: that is, with Swabian (first-generation) interlocutors mainly Swabian was used; in the case of non-Swabian but German-speaking interlocutors, Standard German was used.

Work domain. Quite a few Swabian informants worked for Australian subsidiaries of German firms, two of which are based in Württemberg. Although private communication with Swabian fellow workers might occasionally be in Swabian, the work domain, even if it concerned a German firm, was treated as an English language domain. Functions associated with the High language (such as board meetings, staff meetings) as well as those linked with the Low language (private interaction with colleagues) were predominantly carried out in English. The use of Standard German was restricted to personal interaction with visitors/temporary employees of the parent company. Written communication within the company tended to be in English, whereas communication with the German-based parent company tended to be in Standard German and/or in English (see Clyne 1976 for more details).

School domain. Although the Germans have set up a number of ethnic Saturday schools, none of them cater exclusively or mainly for Swabians. ${ }^{7}$ Unlike the Swiss classes, in which both the High and Low languages are taught, the German classes do not introduce the students to dialects, only to Standard German.

Church domains. Most Swabians in the sample were Lutheran, but only a minority attended church services (either in English or in German). Since the church is identified as a High language domain, Standard German was used in the German services.

\section{Discussion and implications for the future}

In attempting to account for the language strategies displayed by the Limburgs and Swabian speech communities in Australia, I have found the social-identity approach to intergroup relations (see Tajfel and Turner 1979; Hogg and Abrams i.p.) and its application to speech communities (see Giles et al. 1977; Giles and Johnson 1981; McNamara i.p.) useful in providing a plausible interpretation of the observed phenomena.

As indicated before, the Swabian and Limburgs speech communities constitute ethnolinguistic subgroups of the larger German and Dutch speech communities. Their subgroup status is linguistically determined by the diglossia in the community: one variety (the dialect) is unique to their group and one variety (the standard language) is shared with other members of the 
German/Dutch speech community. Because the Limburgers and the Swabians had their own (geographical) territory in their respective home country, daily or frequent contact with other ethnolinguistic subgroups was not a regular feature of the linguistic interactions of the Limburgers or Swabians, at least in the 1950s and early 1960s. Thus, Limburgers and Swabians perceived themselves and were perceived by other members of the Dutch and German speech communities as constituting separate ethnolinguistic (sub)groups.

Migrating to Australia not only brought these two speech communities into contact with another (English-speaking) community but also brought about concurrently a geographical dispersion of their own speech community and closer contact (both linguistic and geographical) with members of Dutch or German speech communities who were not Limburgers or Swabians.

For the latter groups, settlement in Australia thus entailed not only a need to assess their relationship with the 'new' outgroup acting as host community (that is, Australian society) but also with 'old' outgroups (that is, non-Limburgs or non-Swabian members of the Dutch/German speech community). Although both the Swabian and Limburgs groups react similarly with regard to the 'Australian' outgroup - their language-use patterns imply a strategy of gradual linguistic assimilation to the English speech community - the linguistic behavior of the Limburgers vis-à-vis the other members of the Dutch-Australian speech community considerably accelerates the process of language shift. By abandoning the use of Standard Dutch, the variety which they have in common with other members of the Dutch-Australian speech community, in its function as High variety and as lingua franca, the Limburgers signal that their language loyalty does not lie with Standard Dutch and consequently express no interest in LM if this means the maintenance of Standard Dutch. In addition, the fact that they drop the common language variety (that is, Standard Dutch) in favor of English, the language of the new outgroup, for communication with other Dutch immigrants may be interpreted as a strategy to transcend their former minority status vis-à-vis former majority group members, native speakers of Standard Dutch. English may be regarded by them as a neutral choice for the interaction between Limburgs- and non-Limburgs-speaking members of the Dutch speech community in Australia, as neither party can assert linguistic superiority over the other. In a way, using English in these interactions 'attenuates' former linguistic rivalry between the two groups. At the same time, the insistence on using English to fellow-Dutch may be indicative of a willingness (eagerness?) to align themselves with the English speech community and a refusal to exchange their Limburgs group membership for a broader Dutch group membership.

This linguistic behavior has a considerable impact on the process of LS. The Limburgers' unwillingness to use Standard Dutch in Australia implies that the only form of LM they may be interested in would be associated 
with Limburgs, the Low variety. The very nature of the Low variety - a spoken language suitable only for communication of an informal type implies that its potential maintenance would be limited to a very restricted number of domains and functions. There would be neither a promotion of Limburgs for formal language functions or in domains associated with the High variety, nor support by the Limburgs group for (the promotion of Standard) Dutch language broadcasts, Dutch language press, or Dutch language classes in Australia. All in all the future of the Limburgs speech community looks very bleak. The only form of LM in future generations may be the maintenance of Limburgs in its symbolic function, that is, as carrier of cultural heritage and of ritual knowledge relating to Karneval.

The language-use patterns adopted by Swabians in Australia, on the other hand, may be more conducive to LM of Standard German and Swabian than those of the Limburgs group. Maintaining Standard German as the lingua franca for communication with non-Swabian speakers of German and as High variety in a number of German 'ethnic' domains may be indicative of a greater willingness on their part to integrate more into the German speech community at large. Without abandoning their Swabian group membership and identity, they have nevertheless been prepared to assert their 'Germanness' more in the Australian context. Although English has also made inroads into a range of domains, the fact that Swabians have maintained both their (German) varieties may slow down the process of LS. Standard German still has an (admittedly somewhat restricted) role in domains associated with the ethnic community. Swabian cooperation with other German members of the speech community to maintain and promote LM in terms of Standard German in such areas as broadcasting, press, and education is far more likely than in the case of Limburgers vis-à-vis Standard Dutch (see also Clyne, this issue).

\section{Conclusion}

The analysis of two diglossic communities in transition has, it is hoped, indicated the importance of studying the process of LM and LS in the immigrant context in relation to other than 'national' groups. I hope to have shown the relevance of examining intergroup relations (not only in the sense of relations between the host group and the immigrant group, but also between subgroups in the immigrant group) in trying to determine the future and vitality of immigrant languages and speech communities in Australia. Finally, it is hoped that this paper has provided a first insight into the complexities associated with LM/LS issues in relation to diglossic communities. 


\section{Notes}

1. I would like to express my thanks to Jane Bennett, Michael Clyne, Mike Hogg, and Tim McNamara for many useful discussions and suggestions relating to earlier versions of this paper.

2. Although I realized that the reliance on people's recollections of their language use almost 30 years ago was not ideal in establishing premigration language behavior, this procedure was nevertheless regarded as more appropriate than relying on more recent sociolinguistic descriptions of the language situation. The latter do not always describe the language situation prevalent in the 1950 s or $1960 \mathrm{~s}$, the era in which most Limburgs and Swabian informants migrated to Australia. Especially in the Limburgs case, this would lead to a distorted view of the language situation, as the latter underwent considerable changes during the $1960 \mathrm{~s}$.

3. This study was part of a large-scale investigation which is described in Pauwels (1986b).

4. Limburgs, like Swabian, will be used here as a collective noun referring to the many local dialects which make up the Limburgs, or Swabian, dialect group.

5. Prior to the Second Vatican Council, Latin was the High language of the Roman Catholic Church.

6. The Swabians in this project are all post-World War II emigrants from West Germany. For information on the Templars, a small religious community which emigrated from Württemberg to Palestine in the last century and have now settled in Australia, see Clyne, this issue.

7. The Saturday school organized by the Templar community attracts more Swabian speakers, but all of them are the offspring of Templars.

\section{References}

Clyne, M. G. (1976). The languages of German-Australian industry. In Australia Talks, M. G. Clyne (ed.), 117-129. Canberra: ANU Pacific Linguistics.

- (1982). Multilingual Australia. Melbourne: River Seine.

- and Manton, S. (1979). Routines for conducting meetings in Australia: An interethnic study. Ethnic Studies 3 (1), 25-34.

Engel, U. (1954). Mundart und Umgangssprache in Württemberg. Unpublished doctoral dissertation, University of Tübingen.

- (1961). Die Auflösung der Mundart. Muttersprache 71, 129-135.

- (1962). Schwäbische Mundart und Umgangssprache. Muttersprache 72, 257-261.

Ferguson, C. (1959). Diglossia. Word 15, 325-340.

Fishman, J. (1967). Bilingualism with and without diglossia; diglossia with and without bilingualism. Journal of Social Issues 23 (2), 29-38.

Giles, H., Bourhis, R., and Taylor, D. M. (1977). Towards a theory of language in ethnic group relations. In Language, Ethnicity and Intergroup Relations, H. Giles (ed.), 307-438. London: Academic Press.

- and Johnson, P. (1981). The role of language in ethnic group relations. In Intergroup Behaviour, J. C. Turner and H. Giles (eds.), 199-243. Oxford: Blackwell.

Gumperz, J. (1962). Types of linguistic communities. Anthropological Linguistics 4 (1), 28-40.

- (1964). Linguistic and social interaction in two communities. American Anthropologist 67 (2), 37-53. 
Haarmann, H. (1983). Methodologisches zum Begriff der Diglossie und seiner Anwendung. Hitotsubashi Journal of Social Studies 45 (1), 25-43.

Hagen, A. (1975). Diglossie in den Niederlanden. In Gegenwärtige Probleme der Diglossie in germanisch-romanischen Übergangsräumen, W. Besch (ed.), 85-97. Nijmegen: NCDN.

- (1980). Regionale taalvariatie. Nijmegen: NCDN.

- (1981). Standaardtaal en dialectsprekende kinderen. Muiderberg: Coutinho.

Hogg, M. A., and Abrams, D. (i.p.). Social Identity. London: Methuen.

McNamara, T. (i.p.) Language and relations between ethnic groups. Social psychological perspectives. In Issues in Second Language Learning: General and Particular, T. J. Quinn and T. F. McNamara. Geelong: Deakin University Press.

Pauwels, A. (1984). Dialects and language maintenance in Australia. Paper presented at the 7 th AILA World Congress in Brussels, August.

- (1986a). Diglossia, immigrant dialects and language maintenance in Australia: the cases of Limburgs and Swabian. Journal of Multilingual and Multicultural Development 7 (1), 13-30.

- (1986b). Immigrant Dialects and Language Maintenance in Australia: The Cases of the Limburgs and Swabian Dialects. Dordrecht: Foris.

Tajfel, H., and Turner, J. (1979). An integrative theory of group conflict. In Social Psychology of Intergroup Relations, W. G. Austin and S. Worchel (eds.), 33-47. Monterey, Calif.: Brooks/Cole.

Timm, L. (1981). Diglossia: old and new. Anthropological Linguistics 23 (8), 356-367. 